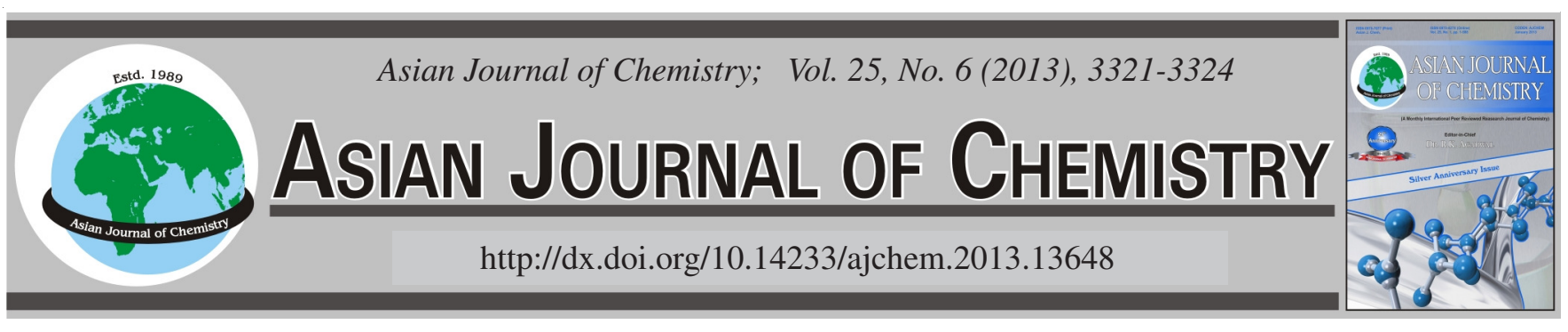

\title{
Highly Sensitive Spectrofluorimetric Determination of Doxycycline Using Doxycycline-Europiumion-Sodium Dodecyl Sulfonate System
}

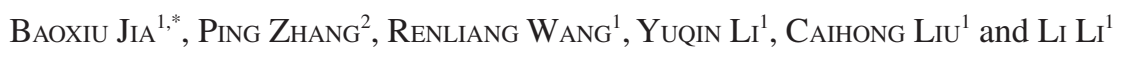

${ }^{1}$ College of Pharmaceutical, Taishan Medical University, Tai'an 271016, P.R. China

${ }^{2}$ Branch of Tai'an Central Hospital, Tai'an 271000, P.R. China

*Corresponding author: Fax: +86 538 6229751; Tel: +86 538 6229751; E-mail: bxjia@tsmc.edu.cn

(Received: 23 February 2012;

Accepted: 19 December 2012)

AJC-12576

\begin{abstract}
A new sepctrofluorimetric method for the determination of doxycycline was developed based on its enhancement of the fluorescence intensity of europium ion in the presence of sodium dodecyl sulfonate. The mechanism of fluorescence enhancement was studied. Optimum conditions for the determination of doxycycline were also investigated. The linear range was $0.10-3.00 \mu \mathrm{g} / \mathrm{mL}$. The detection limit was $1.3 \mathrm{ng} / \mathrm{mL}$. There was no interference from the excipients normally used in tablet formulations and the serum compositions. The proposed method was successfully applied to the determination of doxycycline in tablets and serum.
\end{abstract}

Key Words: Spectrofluorimetry, Europium ion, Doxycycline, Sodium dodecyl sulfonate.

\section{INTRODUCTION}

Doxycycline (DC) is a tetracycline antibiotic that possesses broad-spectrum activity. Its bactericidal properties are based on the inhibition of bacteria cell protein synthesis in Gram-positive and Gram-negative bacteria, spirochetes, mycoplasmas, nocardia, coxiella, rickettsia and chlamydia ${ }^{1}$. After oral administration, doxycycline is almost completely absorbed (95\%). The highest blood level is reached after 1$2 \mathrm{~h}$. Doxycycline plasma half-life ranges from 14 to $22 \mathrm{~h}$ (approximately $18 \mathrm{~h}$ ). Doxycycline has been reported to partially metabolize in liver (30-40\%). 40-55\% of it is unchanged and is excreted in the urine, while some of it makes its way into bile and feces in the form of metabolites.

At present, the analytical techniques that have been employed for the determination of doxycycline were HPLC ${ }^{2,3}$, micellar electrokinetic capillary chromatography ${ }^{4}$, sequential injection (SIA) ${ }^{5}$ and flow injection analysis (FIA $)^{6,7}$. The spectrofluorimetric method has been widely used in the determination of biological samples ${ }^{8,9}$, environmental substances ${ }^{10-12}$ and pharmaceutical ${ }^{13-15}$ because it is highly sensitive, selective, easily operated and economic.

In this paper we show that the fluorescence intensity of $\mathrm{Eu}^{3+}$ is greatly enhanced by doxycycline in the presence of sodium dodecyl sulfonate. The enhanced fluorescence intensity is proportional to the concentration of doxycycline and the detection limit of doxycycline is $1.3 \mathrm{ng} / \mathrm{mL}$. In comparison with most reported methods, our method is quick and simple and has high sensitivity and good stability. This method is used for the determination of doxycycline in the actual samples and the result is satisfactory.

\section{EXPERIMENTAL}

All fluorescence measurements were carried out on a RF5301 recording spectrofluorimeter (Shimadzu, Kyoto, Japan). A UV-2450 recording spectrophotometer (Shimadzu, Kyoto, Japan) was used for the UV spectra scanning and determination experiments. All pH measurements were made with a pHs-3C digital pH-meter (Shanghai Leici Device works, Shanghai, China).

A stock doxycycline (biological product institution of chinese medicine) solution was directly dissolved in water. The working standard solution $(7.50 \mu \mathrm{g} / \mathrm{mL})$ was freshly prepared by appropriate dilution with water. $\mathrm{A} \mathrm{Eu}^{3+}$ ion stock solution was prepared by dissolving $\mathrm{Eu}_{2} \mathrm{O}_{3}$ (Shanghai Yuelong Chemical Plant, Shanghai, China) with a small amount of hydrochloric acid, then diluting to mark with hydrochloric acid $(0.1 \mathrm{~mol} / \mathrm{L})$. The working solution $\left(6.0 \times 10^{-4} \mathrm{~mol} / \mathrm{L}\right)$ was obtained by appropriate dilution with water. A stock solution of surfactant sodium dodecyl sulfonate $\left(1.00 \times 10^{-2} \mathrm{~mol} / \mathrm{L}\right)$ was prepared by dissolving sodium dodecyl sulfonate in deionized water and then diluted to $1.00 \times 10^{-4} \mathrm{~mol} / \mathrm{L}$ as the working solution. A tris- $\mathrm{HCl}$ buffer solution $(0.10 \mathrm{~mol} / \mathrm{L}, \mathrm{pH}$ 7.70) was used for the system. All used chemicals were of analytical or higher grades. Doubly distilled deionized water was used for the preparation of all solutions.

All stocking solutions and working solutions were stored at $0-4{ }^{\circ} \mathrm{C}$. 
Procedure: To $10 \mathrm{~mL}$ colour comparison tubes, solutions were added in the following order: $1 \mathrm{~mL} 7.5 \mu \mathrm{g} / \mathrm{mL}$ doxycycline solution, $2 \mathrm{~mL}$ buffer solution, $1.5 \mathrm{~mL} 1.0 \times 10^{-4} \mathrm{~mol} / \mathrm{L}$ sodium dodecyl sulfonate solution, $1.0 \mathrm{~mL} 6.0 \times 10^{-4} \mathrm{~mol} / \mathrm{L} \mathrm{Eu}^{3+}$ ion solution. The mixture was diluted to the mark with doubly distilled water and stood for $40 \mathrm{~min}$ at room temperature. The fluorescence intensity was measured at $\lambda_{\mathrm{ex}} / \lambda_{\mathrm{em}}=381 / 616 \mathrm{~nm}$. The enhanced fluorescence intensity of $\mathrm{Eu}^{3+}$ by doxycycline was represented as $\Delta \mathrm{F}=\mathrm{F}-\mathrm{F}_{0}$. Here $\mathrm{F}$ and $\mathrm{F}_{0}$ are the fluorescence intensities of the systems with and without doxycycline, respectively.

\section{RESULTS AND DISCUSSION}

Fluorescence spectra: The fluorescence excitation spectrum and emission spectra of 1. $\mathrm{DC}+\mathrm{Eu}^{3+}+\mathrm{SDS}, 2 . \mathrm{DC}+\mathrm{Eu}^{3+}, 3$. $\mathrm{Eu}^{3+}+\mathrm{SDS}$, 4. DC, $5 \mathrm{Eu}^{3+}$ are shown in Fig. 1a and b. From curve 5 in Fig. 1b, it can be seen that single $\mathrm{Eu}^{3+}$ ion solution has nearly no peak. Comparing curve 2 with curve 4 in Fig. 1b, after the addition of $\mathrm{Eu}^{3+}$ ion into the doxycycline solution, doxycycline can form a binary complex with $\mathrm{Eu}^{3+}$ ion. So it appears two little characteristic peaks of $\mathrm{Eu}^{3+}$ ion at 590 and $612 \mathrm{~nm}$ and it is the ${ }^{5} \mathrm{D}_{0^{-}}{ }^{7} \mathrm{~F}_{1}$ transition and ${ }^{5} \mathrm{D}_{0}{ }^{-}{ }^{7} \mathrm{~F}_{2}$ transition of $\mathrm{Eu}^{3+}$ ion, respectively. Comparing curve 1 with curve 2 in Fig. 1b, it can be seen that the characteristic peak of $\mathrm{Eu}^{3+}$ at $612 \mathrm{~nm}$ can be enhanced remarkably after the addition of sodium dodecyl sulfonate, which indicates that sodium dodecyl sulfonate can form a very stable ternary complex with the $\mathrm{DC}-\mathrm{Eu}^{3+}$ complex.
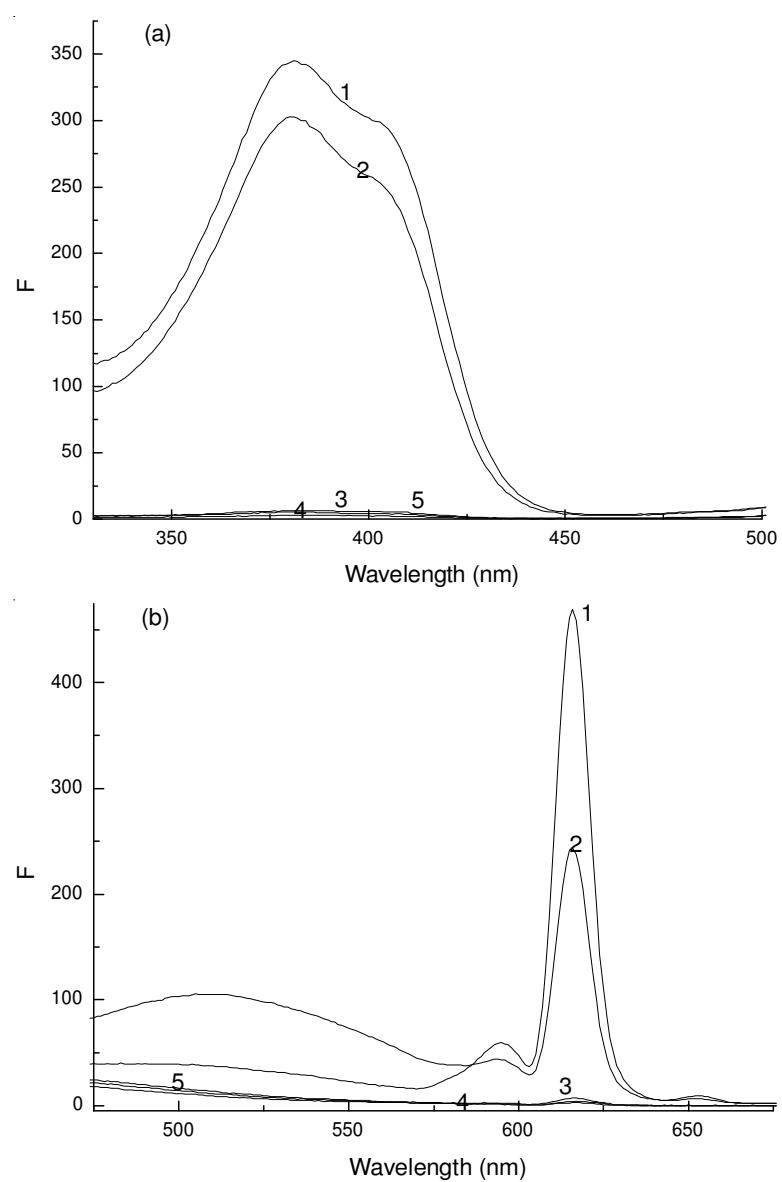

Fig. 1. Fluorescence excitation spectra (a) and emission spectra (b) $\mathrm{C}_{\mathrm{DC}}=$ $0.75 \mu \mathrm{g} / \mathrm{mL}, \mathrm{C}_{\mathrm{Eu} 3+}=6.0 \times 10^{-5} \mathrm{~mol} / \mathrm{L}, \mathrm{pH}=7.7, \mathrm{C}_{\mathrm{SDS}}=1.5 \times 10^{-5}$ $\mathrm{mol} / \mathrm{L}$

\section{Effect of experiment conditions}

Influence of $\mathbf{p H}$ : The $\mathrm{pH}$ dependence of the system was studied over the range 6.1-9.1. The results are shown in Fig. 2. As can be seen, the fluorescence intensity is relatively high and almost remained constant over the $\mathrm{pH}$ range 7.2-8.1. Therefore a $\mathrm{pH}$ of 7.7 was fixed with the use of Tris- $\mathrm{HCl}$ buffer solution.

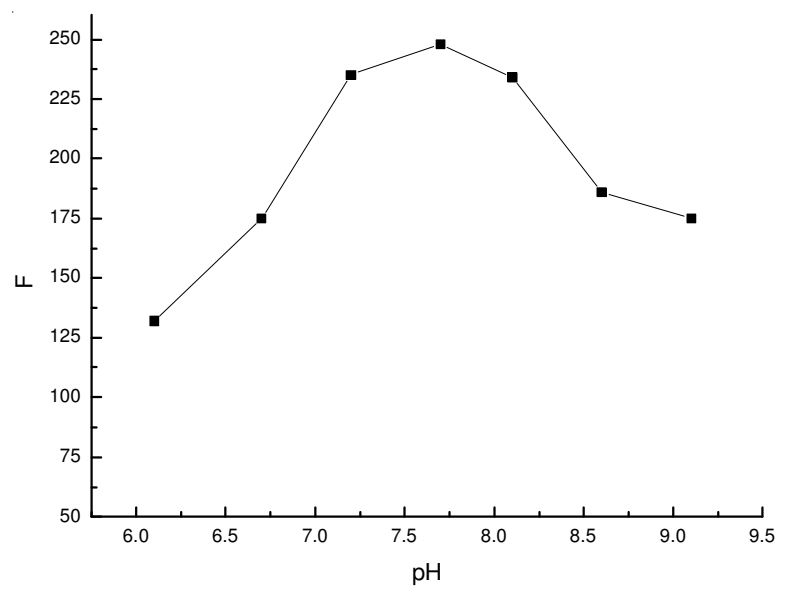

Fig. 2. Influence of $\mathrm{pH}$ on the fluorescence intensity of the complex $\mathrm{C}_{\mathrm{DC}}=$ $0.75 \mu \mathrm{g} / \mathrm{mL}, \mathrm{C}_{\mathrm{Eu} 3+}=6.0 \times 10^{-5} \mathrm{~mol} / \mathrm{L}, \mathrm{C}_{\mathrm{SDS}}=1.5 \times 10^{-5} \mathrm{~mol} / \mathrm{L}$

Effect of the amount of $\mathrm{Eu}^{3+}$ : The influence of the amount of $\mathrm{Eu}^{3+}$ ion on the fluorescence intensities of the solutions containing $0.75 \mu \mathrm{g} / \mathrm{mL}$ of doxycycline and $1.5 \times 10^{-5} \mathrm{~mol} / \mathrm{L}$ of sodium dodecyl sulfonate was studied under the conditions established above. The enhanced fluorescent intensity $\Delta \mathrm{F}$ increased with the increasing amount of $\mathrm{Eu}^{3+}$ ion up to $6 \times 10^{-5}$ $\mathrm{mol} / \mathrm{L}$ and then decreased, as shown in Fig. 3. Thus $6 \times 10^{-5}$ $\mathrm{mol} / \mathrm{L} \mathrm{Eu}^{3+}$ ion (the added amount of $\mathrm{Eu}^{3+}$ ion is $1.0 \mathrm{~mL}$ ) was selected for further study.

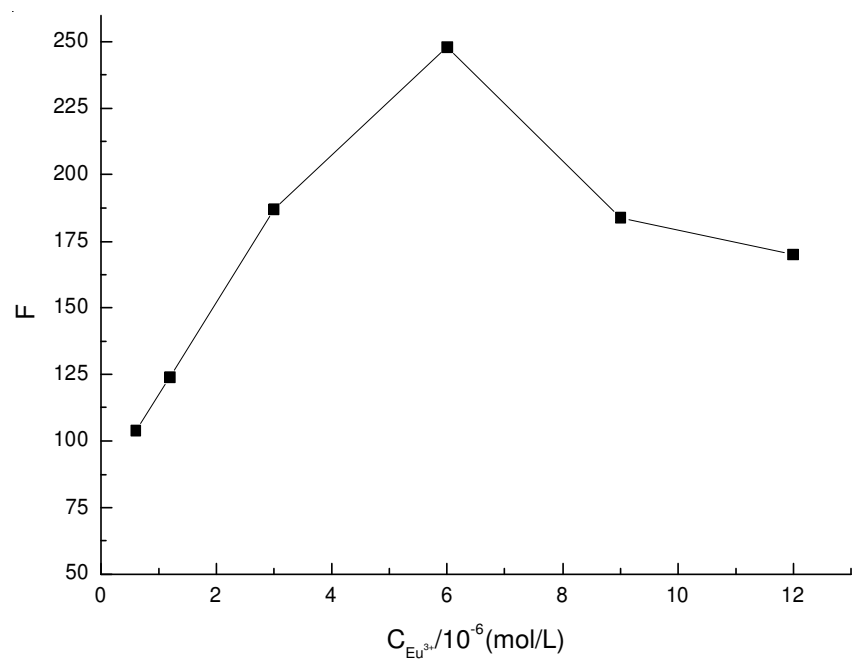

Fig. 3. Influence of $\mathrm{Eu}^{3+}$ on the fluorescence intensity of the complex $\mathrm{C}_{\mathrm{DC}}$ $=0.75 \mu \mathrm{g} / \mathrm{mL}, \mathrm{pH}=7.7, \mathrm{C}_{\mathrm{SDS}}=1.5 \times 10^{-5} \mathrm{~mol} / \mathrm{L}$

Effect of the surfactants and the amout of sodium dodecyl sulfonate: The influence of different surfactants on fluorescence intensity of the system was studied. The results showed that the anionic surfactant sodium dodecyl sulfonate had a strong sensitizing effect and the fluorescence intensity was increased 3 fold. The fluorescence quantum yield (Table-1) 
in different surfactants was determined according to the reference $^{16}$, from which we can see that the sequence of sensitizing effect was: SDS $>$ Tween- $80>$ TX-100 $>$ CTAB $>$ CPB. So we chose sodium dodecyl sulfonate as the sensitizing reagent.

\begin{tabular}{lccc}
\multicolumn{4}{c}{ TABLE-1 } \\
& $\begin{array}{c}\text { EFFECT OF SURFACTANTS ON THE } \\
\text { CHARACTERISTIC OF SPECTRA }\end{array}$ \\
\hline Surfactants & $\lambda_{\mathrm{ex}} / \mathrm{nm}$ & $\lambda_{\mathrm{em}} / \mathrm{nm}$ & $\phi_{\mathrm{f}}$ \\
\hline Water & 381 & 612 & 0.12 \\
CPB & 381 & 613 & 0.13 \\
CTAB & 382 & 614 & 0.14 \\
TX-100 & 382 & 612 & 0.23 \\
SDS & 315 & 616 & 0.41 \\
\hline
\end{tabular}

$\mathrm{C}_{\mathrm{DC}}=0.75 \mu \mathrm{g} / \mathrm{mL}, \mathrm{C}_{\mathrm{Eu} 3+}=6.0 \times 10^{-5} \mathrm{~mol} / \mathrm{L}, \mathrm{pH}=7.7, \mathrm{C}_{\text {surfactant }}=1.5$ $\times 10^{-5} \mathrm{~mol} / \mathrm{L}$

The enhancement reason is supposed as follows: With the addition of surfactants, the protective environment offered by the micelle assemblies can shield the excited species from quenching and nonradiative decay process occurring. On one hand, the adhesive action between the fluorescent molecular and micelle assemblies increases, which avoid the oxygenquenching. On the other hand, the fluorescent molecular lies in the orderly microenvironment, which decreases the speed of the quench and nonradiative decay process. Therefore the fluorescence quantum yield increases.

The influence of the amount of sodium dodecyl sulfonate on the fluorescence intensities of the solutions containing 0.75 $\mu \mathrm{g} / \mathrm{mL}$ of doxycycline and $6.0 \times 10^{-5} \mathrm{~mol} / \mathrm{L}$ of $\mathrm{Eu}^{3+}$ ion was studied under the conditions established above. The enhanced fluorescent intensity $\Delta \mathrm{F}$ increased with the increasing amount of sodium dodecyl sulfonate up to $1.5 \times 10^{-5} \mathrm{~mol} / \mathrm{L}$ and then remains constant (Fig. 4). Thus $1.5 \times 10^{-5} \mathrm{~mol} / \mathrm{L}$ sodium dodecyl sulfonate (the added amount of sodium dodecyl sulfonate is $1.5 \mathrm{~mL}$ ) was selected for further study.

Effect of reaction time: Completing the chelation reaction of $\mathrm{DC}-\mathrm{Eu}^{3+}$-SDS system at room temperature needs at least $40 \mathrm{~min}$. The fluorescence intensity then remains constant for at least $2 \mathrm{~h}$. Therefore, all chelation reactions were carried out for $40 \mathrm{~min}$ and all measurements were made within $2 \mathrm{~h}$.

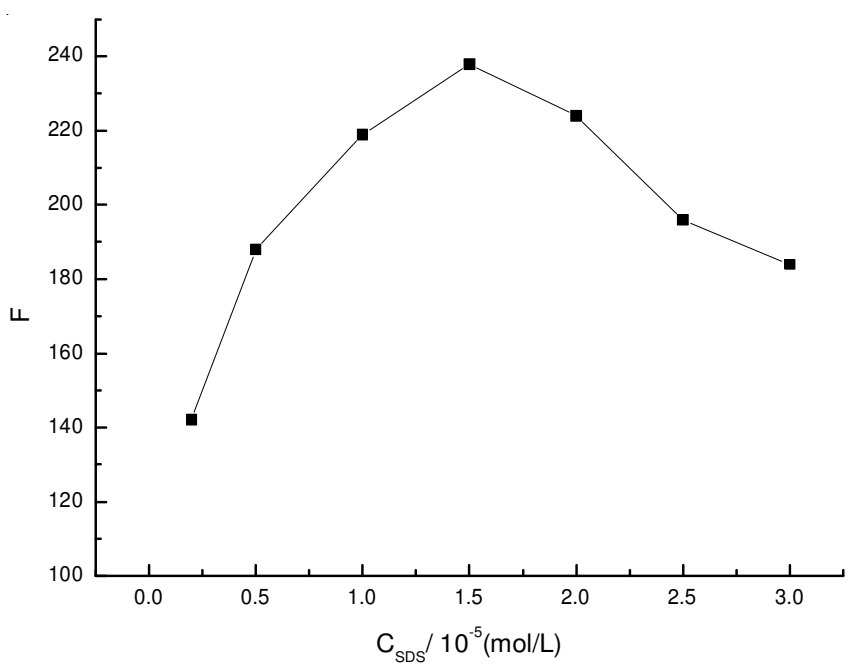

Fig. 4. Influence of sodium dodecyl sulfate on the fluorescence intensity of the complex $\mathrm{C}_{\mathrm{DC}}=0.75 \mu \mathrm{g} / \mathrm{mL}, \mathrm{C}_{\mathrm{Eu} 3+}=6.0 \times 10^{-5} \mathrm{~mol} / \mathrm{L}, \mathrm{pH}=7.7$
Effect of temperature: Temperature had a great effect on the fluorescence intensity of the system. The fluorescence intensity decreases sharply along with the temperature increases. Therefore, we selected room temperature throughout all further work.

Effect of the addition order of reagents: The experimental results showed that adding various reagents in different order had influence on $\mathrm{F}$ and $\Delta \mathrm{F}$. Considering the enhancement of fluorescence intensity of the system, we chose the following order for further study: doxycycline, buffer, sodium dodecyl sulfonate and $\mathrm{Eu}^{3+}$.

Analytical characteristic: Under the experimental conditions, there is a linear relationship between enhanced fluorescence intensity and the concentration of doxycycline in the range of 0.10 to $3.0 \mu \mathrm{g} / \mathrm{mL}$ with a correlation coefficient (r) of 0.998 . The regression equation was $\Delta \mathrm{F}=277.1 \mathrm{C}(\mu \mathrm{g} / \mathrm{mL})+$ 32.4. The limit of detection, as defined by IUPAC ${ }^{17}$, is determined to be $1.3 \mathrm{ng} / \mathrm{mL}$ when the $\mathrm{K}$ value is taken as 3 and the standard deviation is 0.12 obtained from a series of 11 reagent blanks. The relative standard deviation was $1.7 \%$ obtained from a series of 11 standards each containing $0.75 \mu \mathrm{g} / \mathrm{mL}$ of doxycycline.

A comparison of the sensitivity and linear range of this method with other methods for doxycycline is summarized in Table-2. It can be seen that our method has higher sensitivity than most other known methods for the determination of doxycycline.

TABLE-2

COMPARED WITH OTHER METHODS IN SENSITIVITY

\begin{tabular}{|c|c|c|c|}
\hline Method & $\begin{array}{c}\text { Linear range } \\
(\mu \mathrm{g} / \mathrm{mL})\end{array}$ & LOD & Reference \\
\hline HPLC & $25-37$ & 25 & 3 \\
\hline $\begin{array}{l}\text { Sequential } \\
\text { injection }\end{array}$ & $2-100$ & $2 \mu \mathrm{g} / \mathrm{mL}$ & 5 \\
\hline $\begin{array}{l}\text { Flow injection } \\
\text { analysis }\end{array}$ & $0.24-24$ & $4.8 \mu \mathrm{g} / \mathrm{mL}$ & 6 \\
\hline $\begin{array}{l}\text { Flow injection } \\
\text { analysis }\end{array}$ & $4.8-480$ & $0.48 \mu \mathrm{g} / \mathrm{mL}$ & 7 \\
\hline This method & $0.10-3.0$ & $1.3 \mathrm{ng} / \mathrm{mL}$ & $\begin{array}{c}\text { Proposed } \\
\text { method }\end{array}$ \\
\hline
\end{tabular}

Influence of coexisting substances: Before the proposed spectrofluorimetric method was applied to real samples, the influence of the commonly used tablet excipients and the serum compositions on the determination of $0.75 \mu \mathrm{g} / \mathrm{mL}$ doxycycline was studied. A 2000-fold mass excess of them over doxycycline was tested first. If interference occurred, the ratio was reduced progressively until the interference ceased. The criterion for interference was fixed at a $\pm 5.0 \%$ variation of the average fluorescence intensity calculated for the established level of doxycycline. The results (Table-3) showed that the determination was free from the interference of the usual excipients and the serum compositions.

\section{Analytical application}

Determination of doxycycline in tablets: Samples of doxycycline content were satisfactorily determined following the proposed spectrofluorimetric method. The results were shown in Table-4. As can be seen, results obtained by the proposed method agreed with the label claim. 
TABLE-3

EFFECT OF INTERFERENCE ON THE DETERMINATION OF $0.75 \mu \mathrm{g} / \mathrm{mL}$ DOXYCYCLINE (TOLERANCE ERROR $\pm 5.0 \%$ )

\begin{tabular}{cl}
\hline Tolerance ratio in mass & Interference \\
\hline 2000 & $\mathrm{~K}^{+}, \mathrm{Na}^{+}, \mathrm{Cl}^{-}$, Mannitol \\
1500 & $\mathrm{Ca}^{2+}, \mathrm{Mg}^{2+}, \mathrm{Fe}^{3+}$ \\
1000 & $\begin{array}{l}\text { Sorbitol, Sodium chloride, Boracic acid, } \\
\text { Sucrose }\end{array}$ \\
& Glucose, Tryptophan, Glycin, Casein \\
500 & Polyethylene glycol, Gelatin, Merhyl \\
500 & cellulose, Starch, Sodium acetate \\
300 & Gum acacia power \\
100 & Lactose \\
\hline
\end{tabular}

\begin{tabular}{|c|c|c|c|}
\hline \multicolumn{4}{|c|}{$\begin{array}{c}\text { TABLE-4 } \\
\text { DETERMINATION OF DOXYCYCLINE IN } \\
\text { TABLETS }(\mathrm{n}=5, \mathrm{p}=95 \%)\end{array}$} \\
\hline $\begin{array}{l}\text { Pharmaceutical } \\
\text { preparations }\end{array}$ & $\begin{array}{l}\text { Label claim } \\
\left(\mathrm{g} \mathrm{tablet}^{-1}\right)\end{array}$ & $\begin{array}{l}\text { Proposed method } \\
\quad\left(\mathrm{g} \mathrm{tablet}^{-1}\right)\end{array}$ & RSD \\
\hline $\begin{array}{l}\text { Doxycycline } \\
\text { tablets }\end{array}$ & 0.1000 & $\begin{array}{c}0.1006 \\
\pm 0.0015\end{array}$ & 0.72 \\
\hline
\end{tabular}

To evaluate the extraction procedures and the accuracy of the method, a recovery assay was performed. The recoveries of doxycycline added to different concentration sample solutions were shown in Table-5. It can be seen that the recoveries were 95.8-105.1\% and did not beyond the recommended limits of within $\pm 5.0 \%$ of the indicated amount.

\begin{tabular}{ccccc}
\multicolumn{5}{c}{ TABLE-5 } \\
\multicolumn{5}{c}{ RECOVERIES OF THE DETERMINATION OF } \\
DOXYCYCLINE IN TABLETS \\
\hline $\begin{array}{c}\text { Sample } \\
\text { no. }\end{array}$ & $\begin{array}{c}\text { Sample content } \\
(\mu \mathrm{g} / \mathrm{mL})\end{array}$ & $\begin{array}{c}\text { DC added } \\
(\mu \mathrm{g} / \mathrm{mL})\end{array}$ & $\begin{array}{c}\text { DC found } \\
(\mu \mathrm{g} / \mathrm{mL})\end{array}$ & $\begin{array}{c}\text { Recovery } \\
(\%)\end{array}$ \\
\hline 1 & 2.141 & 0.750 & 2.842 & 97.7 \\
2 & 1.426 & 0.375 & 1.813 & 100.8 \\
3 & 0.714 & 1.500 & 2.184 & 95.8 \\
4 & 0.357 & 1.125 & 1.502 & 105.1 \\
\hline
\end{tabular}

Determination of doxycycline in serum: Serum of adult man was mixed with acetonitrile according to the volume ratio of 1:2. The mixture was centrifugal for $5 \mathrm{~min}$. A sample of $2 \mathrm{~mL}$ taken from the centrifugate was transferred into a 100 $\mathrm{mL}$ volumetric flask and diluted to volume with doubly distilled water. To $0.050 \mathrm{~mL}$ of sample solution were added various amounts of doxycycline standard solution. The standard additions method was used in the sample analysis procedure. The results were given in Table- 6 .

\begin{tabular}{ccccc}
\multicolumn{5}{c}{ TABLE-6 } \\
\multicolumn{5}{c}{ DETERMINATION OF DOXYCYCLINE IN } \\
Sample & $\begin{array}{c}\text { Added } \\
\text { NeRUM }(\mathrm{n}=5, \mathrm{p}=95 \%)\end{array}$ \\
No. & $(\mu \mathrm{g} / \mathrm{mL})$ & $(\mu \mathrm{g} / \mathrm{mL})$ & $\begin{array}{c}\text { Recovery } \\
(\%)\end{array}$ & $\begin{array}{c}\text { RSD } \\
(\%)\end{array}$ \\
\hline 1 & 0.75 & $0.69 \pm 0.02$ & 92.1 & 2.1 \\
2 & 1.50 & $1.56 \pm 0.04$ & 104.6 & 1.8 \\
3 & 2.25 & $2.18 \pm 0.07$ & 96.8 & 2.3 \\
\hline
\end{tabular}

\section{Conclusion}

When sodium dodecyl sulfonate and doxycycline are added together to $\mathrm{Eu}^{3+}$, the fluorescence intensity of the system is greatly enhanced. This indicates that there is interaction between doxycycline, sodium dodecyl sulfonate and $\mathrm{Eu}^{3+}$. Based on the enhancement of the fluorescence intensity of $\mathrm{Eu}^{3+}$, a new spectrofluorimetric method for the determination of doxycycline was developed. The developed method was applied to the determination of doxycycline in tablets and serum with satisfactory results.

\section{REFERENCES}

1. L.S. Goodman and A.G. Gilman, The Pharmacological Basis of Therapeutics, McGraw-Hill, New York, edn. 9 (1996).

2. H.T. Lu, Y. Jiang, H.B. Li, F. Chen and M.H. Wong, Chromatographia, 60, 259 (2004)

3. G.C. Innocenzo and P. Fabio, J. Agric. Food Chem., 57, 8735 (2009).

4. I. Rade, K. Javor, K. Samo and S. Borut, Anal. Bioanal. Chem., 387, 695 (2007)

5. D. Satinsky, L.M.L.D. Santos, H. Sklenarova, P. Solich, M.C.B.S.M. Montenegro and A.N. Araujo, Talanta, 68, 214 (2005).

6. N. Wangfuengkanagul, W. Siangoroh and O. Chailapakul, Talanta, 64, 1183 (2004).

7. T. Charoenraks, S. Palaharn, K. Grudpan, W. Siangproh, O. Chailapakul, Talanta, 64, 1247 (2004).

8. Y. Yu, Y. Lai, X.L. Zheng, J.Zh. Wu, Zh.Y. Long and Ch.S. Liang, Spectrochim. Acta A, 68, 1356 (2007).

9. Ch. Q. Jiang and L. Luo, Anal. Chim. Acta, 511, 11 (2004).

10. G.Ch. Han, Y. Peng, Y.Q. Hao, Y.N. Liu and F.M. Zhou, Anal. Chim. Acta, 659, 238 (2010).

11. L. Qhao, X.L. Yan, J.Ch. Guo, D.H. Wang, L. Li, F.Y. Yan and L.G. Chen, Spectrochim. Acta A, 73, 789 (2009).

12. B. Tang, H. Zhang and Y. Wang, Spectrochim. Acta A, 61, 2239 (2005).

13. S.M. Sabry, M. Abdel-Hady, M. Elsayed, O.T. Fahmy and H.M. Maher, J. Pharm. Biomed. Anal., 32, 409 (2003).

14. A. Önal and O. Sagirli, Spectrochim. Acta A, 72, 68 (2009).

15. H.E. Abdellatef, M.M. El-Henawee, H.M. El-Sayed and M.M. Ayad, Spectrochim. Acta A, 65, 1087 (2006).

16. H.M.N.H. Irving, H. Freser and T.S. West, IUPAC. Compendium of Analytical Nomenclature, Definitive Rules, Pergamon Press, Oxford (1978).

17. H.M.N.H. Irving, H. Freiser and T.S. West, IUPAC Compendium of Analyical Nomencature, Definitive Rules, eds., Pergamon Press, Oxford (1981). 